\title{
The net climate impact of coal-fired power plant emissions
}

\author{
D. Shindell and G. Faluvegi \\ NASA Goddard Institute for Space Studies and Columbia University, New York, NY, USA
}

Received: 1 September 2009 - Published in Atmos. Chem. Phys. Discuss.: 9 October 2009

Revised: 23 March 2010 - Accepted: 24 March 2010 - Published: 6 April 2010

\begin{abstract}
Coal-fired power plants influence climate via both the emission of long-lived carbon dioxide $\left(\mathrm{CO}_{2}\right)$ and shortlived ozone and aerosol precursors. Using a climate model, we perform the first study of the spatial and temporal pattern of radiative forcing specifically for coal plant emissions. Without substantial pollution controls, we find that near-term net global mean climate forcing is negative due to the wellknown aerosol masking of the effects of $\mathrm{CO}_{2}$. Imposition of pollution controls on sulfur dioxide and nitrogen oxides leads to a rapid realization of the full positive forcing from $\mathrm{CO}_{2}$, however. Long-term global mean forcing from stable (constant) emissions is positive regardless of pollution controls. Emissions from coal-fired power plants until $\sim 1970$, including roughly $1 / 3$ of total anthropogenic $\mathrm{CO}_{2}$ emissions, likely contributed little net global mean climate forcing during that period though they may have induce weak Northern Hemisphere mid-latitude $(\mathrm{NHml})$ cooling. After that time many areas imposed pollution controls or switched to lowsulfur coal. Hence forcing due to emissions from 1970 to 2000 and $\mathrm{CO}_{2}$ emitted previously was strongly positive and contributed to rapid global and especially $\mathrm{NHml}$ warming. Most recently, new construction in China and India has increased rapidly with minimal application of pollution controls. Continuation of this trend would add negative nearterm global mean climate forcing but severely degrade air quality. Conversely, following the Western and Japanese pattern of imposing air quality pollution controls at a later time could accelerate future warming rates, especially at NHmls. More broadly, our results indicate that due to spatial and temporal inhomogenaities in forcing, climate impacts of multi-pollutant emissions can vary strongly from region to region and can include substantial effects on maximum rateof-change, neither of which are captured by commonly used global metrics. The method we introduce here to estimate regional temperature responses may provide additional insight.
\end{abstract}

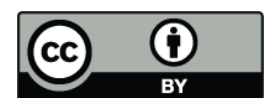

Correspondence to: D. Shindell (dshindell@giss.nasa.gov)

\section{Introduction}

Coal combustion currently produces roughly $27 \%$ of the world's energy, second only to crude oil, and is the largest single source of electricity $(\sim 41 \%)$. Coal is also a major industrial and residential fuel in some countries. At current consumption rates, enough reserves are available to last more than a century (Energy Information Administration, 2009; hereafter EIA, 2009). Nearly half the known reserves are in the US, China and India, countries with large projected increases in energy demand over coming decades. Coal-fired power plants are also currently the least expensive power source in cost to generators per $\mathrm{kWh}$ of electricity. Hence there are enormous economic and socio-political incentives to expanded construction of coal-fired power plants. However, emissions from coal-fired plants have substantial impacts on both air quality and climate change. Large amounts of $\mathrm{CO}_{2}$ are emitted, which lead to warming of the Earth and associated climate changes. Coal-fired power plants also emit substantial amounts of sulfur dioxide $\left(\mathrm{SO}_{2}\right)$, a precursor of fine particulate and acid rain, and of nitrogen oxides $\left(\mathrm{NO}_{\mathrm{x}}\right.$, which is $\left.\mathrm{NO}+\mathrm{NO}_{2}\right)$, gases influencing tropospheric ozone and methane as well as particulate, in addition to producing other pollutants such as mercury and solid waste. Tropospheric ozone and particulate are both harmful to human health, with ozone and sulfur-containing species also damaging to both managed and natural ecosystems, and both influence climate.

Tropospheric ozone, methane, sulfate and nitrate aerosols all change in response to $\mathrm{NO}_{\mathrm{x}}$ and $\mathrm{SO}_{2}$ emissions, which we term the "air quality pollutant" emissions. All these constituents influence climate. Methane responds indirectly to changes in its oxidation rate induced by $\mathrm{NO}_{\mathrm{x}}$ and $\mathrm{SO}_{2}$ emissions, and hence we include it along with the other short-lived air quality pollutants though it is relatively longlived. The balance between the positive radiative forcing (RF) (leading to warming) from $\mathrm{CO}_{2}$ and the sum of RF from the various shorter-lived species will determine the net RF due to emissions from coal-fired power plants. It is

Published by Copernicus Publications on behalf of the European Geosciences Union. 
Table 1. Simple scenarios for emissions from power plants in China and India.

\begin{tabular}{|c|c|c|}
\hline Scenarios over 2000-2080 (Short name) & $\mathrm{CO}_{2}$ emissions & Air quality pollutant emissions \\
\hline Constant current emissions (Constant) & $1132 \mathrm{Tg} \mathrm{CO}_{2}$ & 7.3 $\mathrm{Tg} \mathrm{SO} \mathrm{SO}_{2}, 4.0 \mathrm{Tg} \mathrm{NO}_{2}$ \\
\hline $\begin{array}{l}\text { High growth, late air quality pollution controls } \\
\text { (HighG_lateAQ) }\end{array}$ & $\begin{array}{l}+10 \% / \mathrm{yr} \text { to } 2040, \text { constant } \\
\text { thereafter }\end{array}$ & $\begin{array}{l}+10 \% / \mathrm{yr} \text { to } 2040 \text {, linear decrease to zero } \\
2040-2060\end{array}$ \\
\hline $\begin{array}{l}\text { High growth, early air quality pollution controls } \\
\text { (HighG_earlyAQ) }\end{array}$ & $\begin{array}{l}+10 \% / y r \text { to } 2040, \text { constant } \\
\text { thereafter }\end{array}$ & None \\
\hline $\begin{array}{l}\text { High growth, no air quality pollution controls } \\
\text { (HighG_noAQ) }\end{array}$ & $\begin{array}{l}+10 \% / \mathrm{yr} \text { to } 2040, \text { constant } \\
\text { thereafter }\end{array}$ & $+10 \% / y r$ to 2040, constant thereafter \\
\hline High growth, gas (HighG_gas) & $+6 \% / y r$ & None \\
\hline $\begin{array}{l}\text { Moderate growth, late air quality pollution controls } \\
\text { (ModG_lateAQ) }\end{array}$ & $\begin{array}{l}+5 \% / \mathrm{yr} \text { to } 2060, \text { constant } \\
\text { thereafter }\end{array}$ & $\begin{array}{l}+5 \% / y r \text { to } 2040 \text {, linear decrease to zero } \\
2040-2060\end{array}$ \\
\hline $\begin{array}{l}\text { Moderate growth, early air quality pollution controls } \\
\text { (ModG_earlyAQ) }\end{array}$ & $\begin{array}{l}+5 \% / y r \text { to } 2060, \text { constant } \\
\text { thereafter }\end{array}$ & None \\
\hline $\begin{array}{l}\text { High growth until 2030, late air quality pollution } \\
\text { controls (HighG2030_lateAQ) }\end{array}$ & $\begin{array}{l}+10 \% / \mathrm{yr} \text { to } 2030, \text { constant } \\
\text { thereafter }\end{array}$ & $\begin{array}{l}+10 \% / y r \text { to } 2030 \text {, linear decrease to zero } \\
2030-2050\end{array}$ \\
\hline $\begin{array}{l}\text { High growth until 2030, early air quality pollution } \\
\text { controls (HighG2030_earlyAQ) }\end{array}$ & $\begin{array}{l}+10 \% / \mathrm{yr} \text { to } 2030, \text { constant } \\
\text { thereafter }\end{array}$ & None \\
\hline
\end{tabular}

well-known that aerosol forcing has masked a substantial portion of the RF from $\mathrm{CO}_{2}$ during the past century at the global scale (e.g. Wigley, 1991; Charlson et al., 1992; Taylor and Penner, 1994; Dufresne et al., 2005; Andreae et al., 2005), and that it is important to consider both emissions of $\mathrm{CO}_{2}$ and other species in assessing abatement strategies (e.g. Shindell et al., 2009; Berntsen et al., 2006). However, this general knowledge is not enough to allow us to understand the impact of emissions from a specific sector or activity.

Several recent studies have attempted to provide such policy-relevant information by quantifying the RF due to all emissions from particular economic sectors or activities (e.g. Aunan et al., 2009; Fuglestvedt et al., 2008; Unger et al., 2009; Unger et al., 2008; Koch et al., 2007). These studies primarily calculated global mean forcing, however, while owing to the vast difference in lifetime among these pollutants (days to months for aerosols and ozone, roughly a decade for methane, and centuries for $\mathrm{CO}_{2}$ ) the forcing will be neither spatially nor temporally uniform. In an earlier study, we did examine the regional forcing due to specific emission sectors (Shindell et al., 2008a), but for broad sectors that include multiple activities (e.g. all types of power generation). Emissions from coal-fired power plants, which as noted yield large quantities of air quality pollutants, are quite different from gas-fired plants, for example. The impact of this difference has been explored in detail (Hayhoe et al., 2002), but again only for the global mean RF. Here we build upon these previous studies by investigating both the spatial and temporal dependence of the net climate forcing from and the response to emissions from a single activity: coal-fired power plants. We hope this example illustrates the detailed information that is required to inform policy-makers of the full breadth of the complex impacts associated with any individual activity which leads to emissions of multiple pollutants.

\section{Scenarios}

We first examined the impact of a static number of coal plants using current worldwide emissions and those from China and India alone. We then looked at hypothetical future growth focusing on China and India since they are projected to account for $80 \%$ of the growth in coal-fired power generation over coming decades (EIA, 2009). Several simple illustrative scenarios for 2000-2080 with different rates of growth in the number of power plants, timing of air quality pollutant controls, and fuel use were explored (Table 1). Several simple illustrative scenarios for 2000-2080 with different rates of growth in the number of power plants, timing of air quality pollutant controls, and fuel use were explored (Table 1). We begin our scenarios at 2000 as this is the most recent year for which we have complete emissions inventories. The yearon-year growth rate in GtC used in coal-fired plants in China has been $10.1 \%$ during 2000-2006, with a growth rate of $16.4 \%$ per year from 2003-2006 (EIA, 2009). The long-term growth rate has averaged $5.9 \%$ from 1981 to 2006 . Hence we examined high-growth scenarios ('HighG' cases), assuming a $10 \% / y e a r$ increase in coal power plant emissions in China and India, and moderate growth using 5\%/year ("ModG" cases). While the global recession has caused a recent slowdown in power plant construction, and future growth rates may well be lower, the Chinese government has said that coal will remain its major energy source despite the impact on global warming (The China Post, 2009). Hence investigation of the impact of growth rates analogous to those in 
past years seems warranted. For comparison, growth in energy produced from coal between 2000 and 2050 in the SRES scenarios ranged from $-78 \%$ to $+679 \%$ (Nakicenovic et al., 2000). Our scenarios span $+174 \%$ to $+713 \%$ for this time period, which overlaps fairly well with and covers a large portion of the SRES range.

World coal reserves are estimated at $930 \mathrm{Gt}$ coal (EIA, 2009). In the high-growth scenario, usage grows very rapidly as time progresses due to the geometric increase when applying a constant percentage growth. We stop the increase in power plant capacity when $1 / 4$ of world reserves have been used up solely by the additional usage in China and India (i.e. $232 \mathrm{Gt}$ used), which is in year 40 for a $10 \% / \mathrm{yr}$ growth rate. Maintaining constant usage after 2040 exhausts current reserves at 2075 under that scenario. As the date at which growth ceases has a strong effect on the total usage, we also include a high-growth scenario where growth terminates at 2030 instead of 2040. Air quality pollution controls (removal of $\mathrm{SO}_{2}$ and $\mathrm{NO}_{\mathrm{x}}$ ) are imposed either at the start of the scenario ("earlyAQ" cases) or at the end of the addition of coalfired power plants (2030 or 2040; "lateAQ" cases). In the former cases, we assume full air quality pollutant controls are put in place as new plants are constructed, so there are no air quality pollutant emissions. In the latter, we assume air quality pollutant controls are gradually retrofitted to the plants constructed since 2000 over 20 years (2031-2050 or 2041-2060) during which time the $\mathrm{SO}_{2}$ and $\mathrm{NO}_{\mathrm{x}}$ emissions both decrease linearly to zero. An additional high-growth scenario never imposes pollution controls, even after all new construction ceases in 2040. This provides another view of the emissions of a constant number of power plants, as in the first "constant current emissions" case, but this time including the effects of the $\mathrm{CO}_{2}$ emissions during the earlier years when the number of plants was increasing (i.e. $\mathrm{RF}$ at a given time in this scenario after 2040 is due to $\mathrm{SO}_{2}$ and $\mathrm{NO}_{\mathrm{x}}$ emissions at that time plus the effect of all $\mathrm{CO}_{2}$ emitted from 2000 to that time). In the moderate-growth scenarios, new plants are added until 2060, but pollution controls are still imposed at 2040 (Table 1).

Finally, we include a scenario for comparison in which growth of $10 \%$ per year in year 2000 coal-fired power capacity is again assumed, but all additional capacity is generated through natural gas rather than coal. $\mathrm{CO}_{2}$ emissions are $15 \mathrm{~kg} \mathrm{C} / \mathrm{GJ}$ from gas-fired power plants, as compared with $25 \mathrm{~kg} \mathrm{C} / \mathrm{GJ}$ from coal-fired plants (Ramanathan and Feng, 2008), but virtually no $\mathrm{SO}_{2}$ or $\mathrm{NO}_{\mathrm{x}}$ is generated from gas combustion. Hence the effect is a $40 \%$ drop in $\mathrm{CO}_{2}$ emissions relative to coal and a complete removal of air quality pollution effects. Note that neither coal- nor gas-fired power plants emit substantial quantities of carbonaceous aerosols (black and organic carbon). In all scenarios, all emissions other than these changes in power generation-related emissions are held fixed as we wish to examine the RF due to these emissions alone.
Table 2. Year 2000 emissions from coal-fired power generation (Tg or $\mathrm{Mt})$.

\begin{tabular}{llll}
\hline & China & India & US \\
\hline $\mathrm{CO}_{2}$ & 771 & 361 & $2442(2517)$ \\
$\mathrm{SO}_{2}$ & 5.4 & 1.9 & $12.0(9.0)$ \\
$\mathrm{NO}_{\mathrm{x}}$ & 2.7 & 1.3 & $5.6(3.7)$ \\
\hline
\end{tabular}

Footnotes to Table 2: Emissions are in $\mathrm{Tg} \mathrm{CO}_{2}, \mathrm{Tg} \mathrm{SO}_{2}$ and $\mathrm{Tg} \mathrm{NO}$. Conversion from PJ coal used for power to emissions based on $29.3 \mathrm{GJ}$ per ton of coal. Emission factors are $16 \mathrm{~g}$ $\mathrm{SO}_{2} / \mathrm{kg}$ coal for China and $12 \mathrm{~g} / \mathrm{kg}$ for India, $8 \mathrm{~g} \mathrm{NO}_{2} / \mathrm{kg}$ coal for both, and $2278 \mathrm{~g} \mathrm{CO}_{2} / \mathrm{kg}$ coal for both based on mid-range values (Streets et al., 2003). US data is also given for 2007 in parentheses (US data from EIA, 2009) (http://www.eia.doe.gov/cneaf/ electricity/epa/epates.html).

\section{Experimental setup}

We examined the radiative forcing relative to the year 2000 due to these hypothetical scenarios for emissions of $\mathrm{CO}_{2}$, $\mathrm{SO}_{2}$ and $\mathrm{NO}_{\mathrm{x}}$. We first performed full three-dimensional chemistry-climate model calculations of the effect of increasing $\mathrm{SO}_{2}$ and $\mathrm{NO}_{\mathrm{x}}$ from China and India. In these calculations, aerosol and ozone precursor emissions from coalfired power plants were increased throughout China (20$48 \mathrm{~N}, 100-125 \mathrm{E})$ and India (5-30 N, 65-90 E). Base case emissions for all species and sectors are the 2000 inventory of the International Institute for Applied Systems Analysis (IIASA) which is based on the 1995 EDGAR3.2 inventory, extrapolated to 2000 using national and sector economic development data (Dentener et al., 2005). For the power sector, the IIASA inventory provides the spatial distribution of emissions. The magnitude of emissions specifically originating in coal-fired power generation is taken from a detailed species- and sector-specific 2000 inventory for Asia (Streets et al., 2003) (Table 2).

Calculations were performed using the compositionclimate model G-PUCCINI to calculate the atmospheric composition response to the $\mathrm{SO}_{2}$ and $\mathrm{NO}_{\mathrm{x}}$ emissions changes and their radiative forcing. This model incorporates gasphase (Shindell et al., 2006), sulfate (Koch et al., 2006) and nitrate (Bauer et al., 2007) aerosol chemistry within the GISS ModelE general circulation model (Schmidt et al., 2006). The model used here has 23 vertical layers and 4 by 5 degree horizontal resolution. Evaluations of the present-day composition in the model against observations are generally quite reasonable (as documented in the references given above). The model was initially integrated for 5 years to allow adjustment of ozone and aerosol concentrations to emissions. Annual average all-sky aerosol optical depths (AOD) during the initial 5-yr period are 0.040 for sulfate and 0.020 for nitrate. A recent comparison of multiple models (Schulz et al., 2006) shows a mean sulfate AOD of 0.035 (range 0.015 to 0.055 ), 

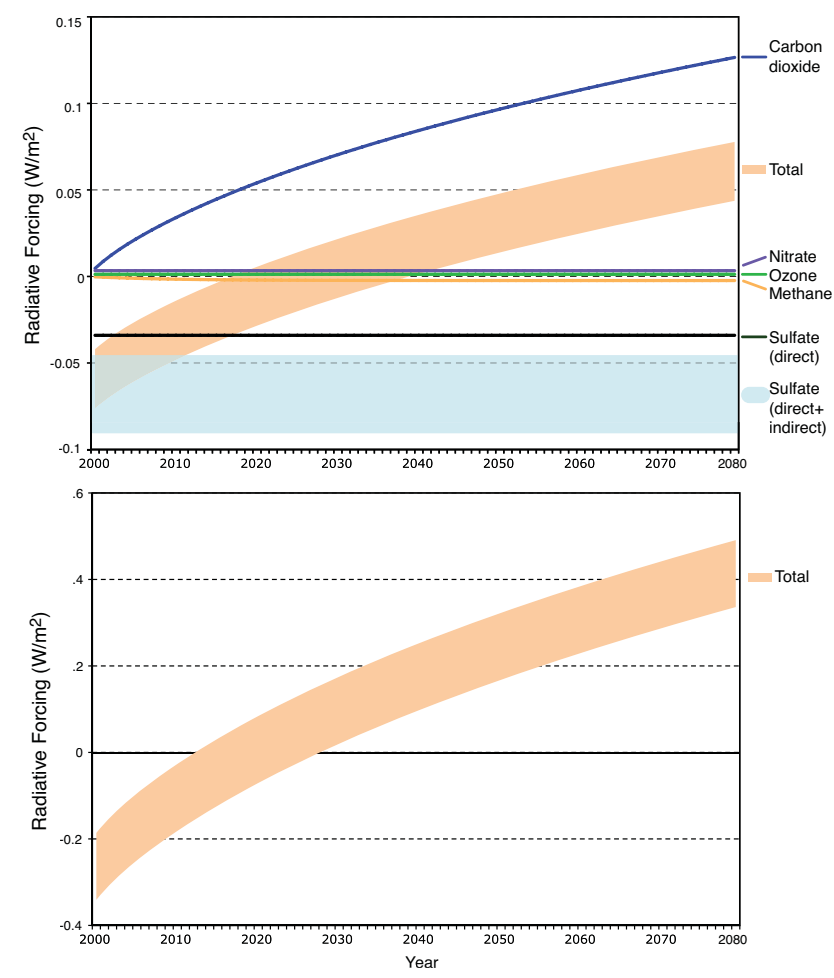

Fig. 1. Timeseries of global mean annual average radiative forcing for the case of constant emissions from coal burning power plants. Emissions are year 2000 emissions in China and India (upper panel) and worldwide from coal-burning power plants (lower panel). In the upper panel, values are shown for individual forcing agents as well as for the total forcing, with all values relative to 2000 and including only emissions from 2000 onward. Forcings are adjusted values at the tropopause (in all figures).

so that our values are mid-range. Observational constraints on the all-sky value are not readily available, as most of the extant measurement techniques are reliable only in clear-sky (cloud-free) conditions. Sampling clear-sky areas only, the model's global total AOD for all species is 0.14 , while observations give global mean values of 0.135 (ground-based AERONET) or 0.15 (satellite composites), though these have substantial limitations in their coverage (Kinne et al., 2006). The radiative forcing per unit burden change in this model has been discussed and compared with other models previously (Shindell et al., 2008b; Schulz et al., 2006) (see discussion in Sect. 6). Following initialization, the composition response to increasing emissions was simulated from 2000 to 2040.

The direct RF due to ozone and aerosols was calculated internally within the climate model. Aerosol indirect effects (AIE) are highly uncertain (Penner et al., 2006; Forster et al., 2007) and hence not robustly characterized using a single model. To provide a rough idea of the magnitude of potential AIE, we include their effect using the conservative estimate that they are equal to the direct effect from sulfate aerosols. Calculations based on detailed modeling and ob- servations suggest that the ratio of AIE to direct sulfate RF is 1.5 to 2.0 (Kvalevåg and Myhre, 2007), but we use a lower value of 1.0 as AIE may saturate at the very large regional sulfate loadings reached in our simulations, and recent analyses based on satellite data suggest that at least a portion of the AIE may be fairly weak (Quaas et al., 2008). We include an uncertainty of a factor of three in the AIE estimate (50\%), similar to the ranges given in recent assessments (Penner et al., 2006; Forster et al., 2007) and large enough to reasonably characterize the overall uncertainty in sulfate aerosol forcing. Uncertainties in greenhouse gas forcings are neglected as these are very small in comparison with aerosol-related forcing uncertaintes.

The response to $\mathrm{CO}_{2}$ emissions was calculated using impulse response functions derived from the Bern Carbon Cycle Model (Siegenthaler and Joos, 1992) based on the version used in the IPCC TAR. Exponential fits to those functions are used to calculate the $\mathrm{CO}_{2}$ concentration at a given year resulting from all emissions in prior years. This approach is expected to yield fairly similar results to a more sophisticated carbon cycle model for the cases studied here, at least until the latter part of the $21^{\text {st }}$ century when $\mathrm{CO}_{2}$ level become substantially larger in some scenarios and could induce additional feedbacks. We also perform an offline calculation of the steady-state methane response to changes in modeled oxidants, as in prior work (Shindell et al., 2008a). As methane is prescribed at present-day values in the chemistry model, changes in modeled methane oxidation result solely from changes in oxidizing agents, and fully capture spatial and seasonal variations. We also include the feedback of methane on its own lifetime (using $\delta \ln (\mathrm{OH})=-0.32 \delta \ln \left(\mathrm{CH}_{4}\right)$ as recommended in Prather et al., 2001). We include the slow response of ozone to the decadal timescale changes in methane, the so-called primary mode ozone (Wild et al., 2001), based on prior modeling (Shindell et al., 2005). Radiative forcing from $\mathrm{CO}_{2}$ and methane are calculated using the standard IPCC TAR formulation (Ramaswamy et al., 2001). All values are adjusted forcing (allowing stratospheric temperatures to respond) at the tropopause.

\section{Radiative forcing results}

We first examine the net radiative forcing from $\mathrm{CO}_{2}$, sulfate, ozone, methane and nitrate for the reference cases of constant emissions from power plants. These cases include only emissions from the present and future, and do not account for any prior emissions from these plants. They thus provide a reference for the effect of newly added plants, or for the effect of those emissions that can still be affected by policy for existing plants. The influence of historical emissions from current plants is discussed later (Sect. 5). Using current emissions from China and India that are largely without pollution controls (Fig. 1; upper panel), we see that there is an immediate negative overall forcing that slowly decreases 
with time and eventually turns into a positive forcing as $\mathrm{CO}_{2}$ accumulates in the atmosphere. In addition to $\mathrm{CO}_{2}$, forcing is dominated by the direct and indirect effects of increased sulfate aerosol (due to the $\mathrm{SO}_{2}$ emissions), with a small addition from reduced methane (due to increased $\mathrm{NO}_{\mathrm{x}}$ and hence ozone and $\mathrm{OH})$. There are very small positive forcings from increased ozone (due to the $\mathrm{NO}_{\mathrm{x}}$ emissions) and decreased nitrate aerosol. The latter arises from a greater formation of ammonium sulfate at the expense of ammonium nitrate (as there is competition for the limited supply of ammonium). The net result is that the short-term climate impact of coal burning in power plants without pollution controls is opposite to the long-term impact, with the transition time ( $\sim 20$ 40 years) highly dependent upon the magnitude of the AIE. Note that the results were highly linear despite pollutant increases up to a factor of 40 . However, photochemical regimes (sunlight and cloud cover, temperature, removal rates, etc.) and background concentrations do vary with geographic location, and can lead to differences as large as a factor of 2 in the RF per unit $\mathrm{SO}_{2}$ emission change (Shindell et al., 2008a). Thus our results are specific to emissions from Asia, though typically regional differences are fairly small and well within the uncertainty ranges given here. Hence these results can also provide a fairly rough estimate for the instantaneous RF of US (or European) emissions during the early 1970s, which were comparable in magnitude to those from China and India in 2000 .

To put the future forcing from added power plants in context, we also show the total forcing from current worldwide emissions from coal-burning power plants (Fig. 1; lower panel). In this case, we have assumed that air quality pollutant emissions per Gt coal burnt in other OECD countries are comparable to those in the US and in other non-OECD countries they are comparable to those in India. Total coal use was taken from EIA (2009). Results are similar to those for China and India alone but with greater magnitude and an earlier transfer time from negative to positive forcing due to the presence of air quality pollutant emission controls in many parts of the world. These results are not intended to be a control scenario, but instead serve as references for constant current emissions to allow comparison of the effects of new plants with those of existing plants and to see how forcing from a particular plant changes with time.

We next examine results from the hypothetical scenarios for additional plants in China and India (Fig. 2). The highgrowth scenarios show that the timing at which pollutant controls are imposed has an enormous effect on the net RF over the next several decades. The HighG_earlyAQ scenario shows a net forcing of nearly $0.7 \mathrm{~W} / \mathrm{m}^{2}$ at 2040 , while the HighG_lateAQ scenario has a forcing in the range of -0.3 to $-1.0 \mathrm{~W} / \mathrm{m}^{2}$. Hence until they are controlled, the air quality pollutants emitted by a steadily increasing number of power plants exert an even more powerful, but opposite sign, global mean forcing than the $\mathrm{CO}_{2}$ emissions. However, the timing of pollution controls has no effect on the radiative forcing

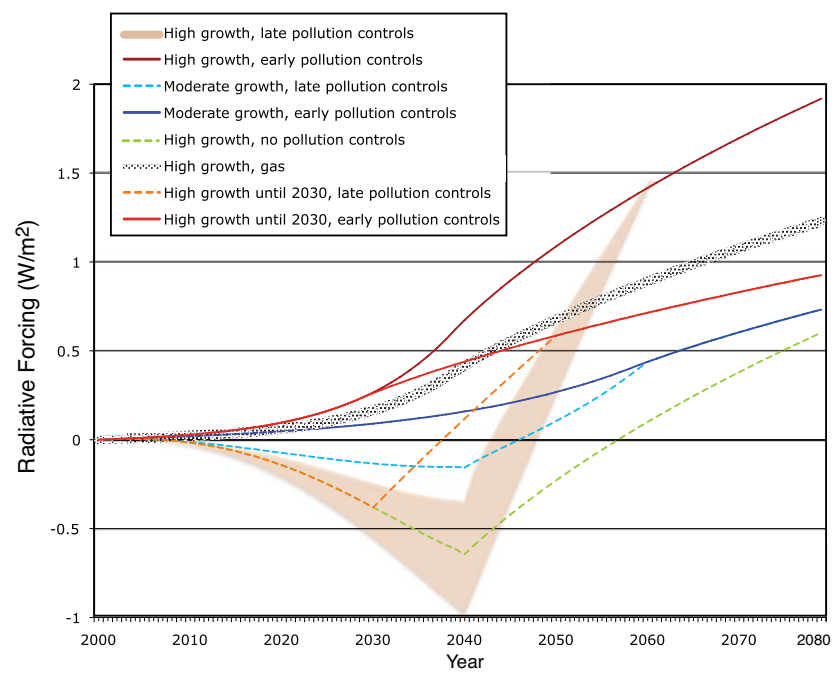

Fig. 2. Timeseries of global mean annual average radiative forcing relative to the year 2000 in the various indicated scenarios. Note that the high growth scenarios are shown in red-orange-green colors and the moderate growth in blues. Forcing is the sum of contributions from carbon dioxide, sulfate, ozone, methane and nitrate. Dashed lines are those scenarios with substantial aerosol forcing (late or no pollution controls). The shaded region shows the uncertainty associated with aerosol forcing in the "High_late" case as an example. All the dashed lines would have comparable uncertainty ranges (the others are omitted for visual clarity).

once those controls are fully in place, leading to identical values past 2060 in the earlyAQ and lateAQ high-growth scenarios (there will be an effect on the integrated RF felt by the Earth however, which will impact the trajectory of the surface temperature climate response even if not the final state, as discussed in Sect. 5). The high-growth scenarios show a continued increase in RF throughout the period studied despite constant emissions after 2040. The continued increase, which is still fairly rapid at $2080\left(0.25 \mathrm{~W} / \mathrm{m}^{2}\right.$ per decade $)$ results from the long adjustment time of atmospheric $\mathrm{CO}_{2}$ to emissions.

The high-growth scenarios in which growth ceases at 2030 instead of 2040 show substantially less forcing during the latter part of the century. Forcing at 2080 is roughly half in comparison with the scenarios in which growth persists until 2040. A large impact is not surprising given that adding $10 \%$ per year coal-fired power generation capacity from 2030 2039 increases annual average total coal usage by $260 \%$.

The overall growth rate (high vs. moderate) has a greater impact on the forcing in our various scenarios in the later decades than the year at which growth ceases or even whether air quality pollution controls are imposed at all. A more modest $5 \%$ per year growth rate all the way though 2060 leads to $60 \%$ less RF at 2080 than a $10 \%$ per year growth rate through 2040. Use of gas instead of coal also leads to decreased forcing, but not as dramatic a reduction as lowering the growth rate by half. 


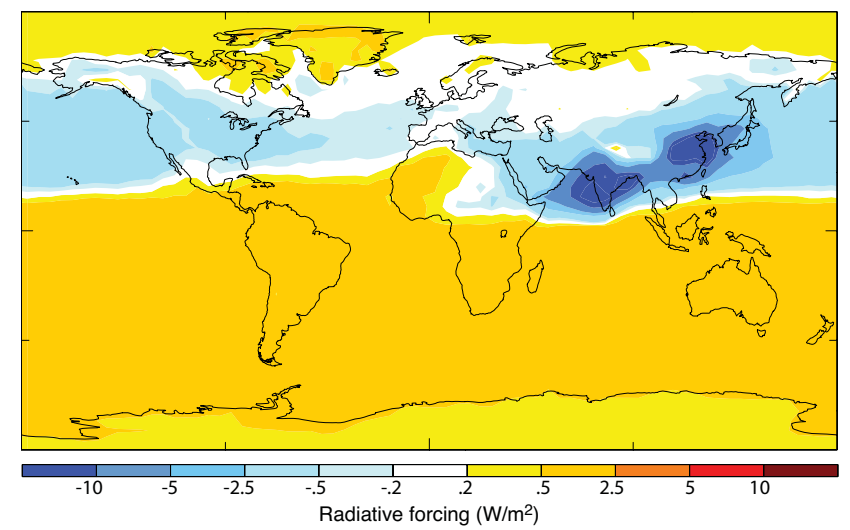

Fig. 3. Annual average radiative forcing for the high growth, late air quality pollution controls scenario in 2046 , when the net global mean forcing is zero. The forcing includes contributions from $\mathrm{CO}_{2}$, methane, ozone, sulfate (direct plus estimated indirect), and nitrate, whose global mean values are $0.96,-0.04,0.03,-0.99$ and $0.05 \mathrm{~W} / \mathrm{m}^{2}$, respectively. Forcing calculations were done internally in the GISS climate model other than the aerosol indirect effects which were estimated based on the sulfate forcing as described in the text, and the methane and $\mathrm{CO}_{2}$ forcings which were calculated using the TAR formulation (Ramaswamy et al., 2001).

Though the global mean forcing provides a reasonably good indication of the global mean temperatures response, regional responses depend upon the geographic distribution of forcing, and the forcing in the cases with substantial pollution from aerosols and ozone is highly uneven spatially. An interesting example of this is the year 2046 in the HighG_lateAQ case, during which the global mean radiative forcing is zero (Fig. 3). The forcing from air quality pollutants is the sum of several components with varying atmospheric residence times, as discussed previously. The net effect is dominated by sulfate, whose global mean negative RF in this case is $-0.99 \mathrm{~W} / \mathrm{m}^{2}$, approximately 12 times larger than the sum of positive ozone and nitrate forcings ( 0.03 and $0.05 \mathrm{~W} / \mathrm{m}^{2}$, respectively). Though the global mean sulfate forcing almost exactly offsets the positive $0.96 \mathrm{~W} / \mathrm{m}^{2}$ forcing from $\mathrm{CO}_{2}$, the various forcings do not cancel at local, regional, or even hemispheric scales. Sulfate, ozone and nitrate forcings are greatest locally over the Asian source regions, but the forcing spreads zonally (east-west) around the Northern Hemisphere given the days-to-weeks lifetime for ozone and aerosols. In contrast, the indirect methane decreases are globally fairly uniform owing to methane's much longer residence time, and offset a small portion $(\sim 4 \%)$ of the global $\mathrm{CO}_{2}$ forcing. Net forcing at 2046 in the HighG_lateAQ scenario is positive $\left(0.3-1 \mathrm{~W} / \mathrm{m}^{2}\right)$ over most of the tropics, Southern Hemisphere and the Arctic. Closer to the source, negative forcing of more than $-10 \mathrm{~W} / \mathrm{m}^{2}$ occurs over much of China and India, with negative values of a few tenths of a $\mathrm{W} / \mathrm{m}^{2}$ extending across most of the Northern Hemisphere mid-latitudes. Looking at the year of peak aerosol forcing

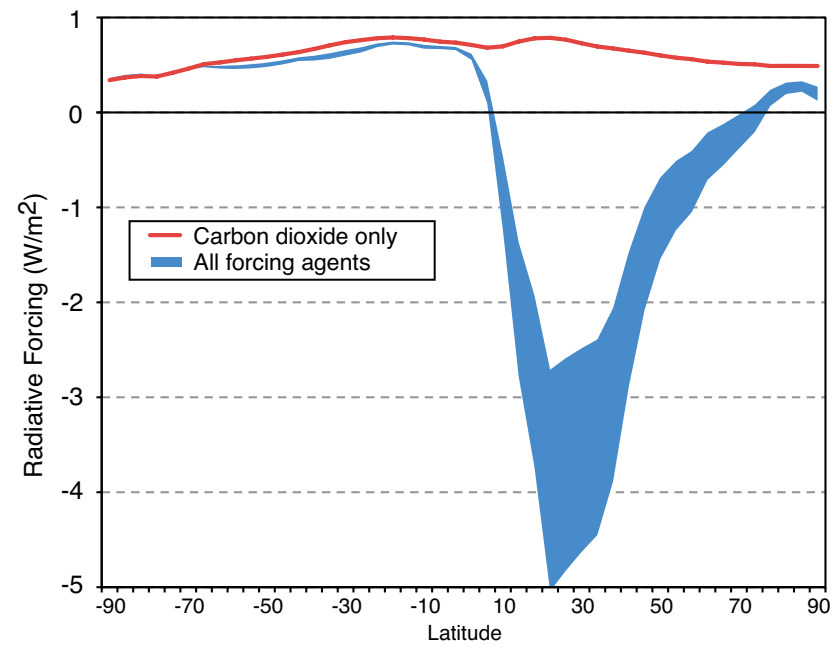

Fig. 4. Annual average radiative forcing in 2040 for the high growth, late air quality pollution controls scenario as in Fig. 3, but for the peak aerosol forcing year 2040 and showing zonal mean values for $\mathrm{CO}_{2}$ forcing only and for the total forcing. The global mean forcing by species in $\mathrm{W} / \mathrm{m}^{2}$ are: 0.68 for $\mathrm{CO}_{2},-0.05$ for methane, 0.04 for ozone, -1.46 for sulfate (direct plus indirect) and 0.08 for nitrate.

in the same HighG_lateAQ scenario, 2040, the zonal mean forcing is strongly negative in the Northern Hemisphere subtropics and mid-latitudes, and positive elsewhere (Fig. 4). In contrast, forcing is positive and fairly uniform in the case with early pollution controls (for which the total forcing is equivalent to the $\mathrm{CO}_{2}$ forcing shown in Fig. 4). We note that zonal mean forcing is likely to be a reasonably good indicator of the zonal mean climate response, which does not closely follow the RF at regional scales but appears to be strongly related for broad latitude bands (Taylor and Penner, 1994; Shindell et al., 2007; Shindell and Faluvegi, 2009; Levy et al., 2008; Mitchell et al., 1995; Kloster et al., 2009) with the exception of polar latitudes that are highly sensitive to non-local forcing via perturbed heat transport (Shindell, 2007; Boer and Yu, 2003; Jones et al., 2007).

\section{Climate response and historical context}

We estimate the surface temperature response to the calculated radiative forcings following the methodology used in calculation of global temperature potentials (Shine et al., 2005), but extending this to regional temperatures using prior results from transient simulations with the GISS climate model (Shindell and Faluvegi, 2009; Hansen et al., 2007). In essence, we obtain an approximation of global and regional responses by multiplying the calculated RF by the global or regional transient sensitivity which accounts for ocean inertia. While many simple global energy balance models exist, our calculations allow estimation of regional responses 
including the influence of both local and remote forcings using the results of (Shindell and Faluvegi, 2009) and the spatial patterns of forcing calculated here (e.g. Fig. 3). In our calculations, the surface temperature change in area $a$ between time 0 and time $t$ is given by:

$$
\begin{aligned}
& d T_{a}(t)=\int_{0}^{t}\left(\left(k_{\text {SHext }, a} \times F_{\text {SHext }}\left(t^{\prime}\right)+k_{\text {Tropics }, a} \times F_{\text {Tropics }}\left(t^{\prime}\right)\right.\right. \\
& \left.\left.+k_{\mathrm{NHml}, a} \times F_{\mathrm{NHml}}\left(t^{\prime}\right)+k_{\text {Arctic }, a} \times F_{\text {Arctic }}\left(t^{\prime}\right)\right) / k_{\text {Global }, a}\right) \\
& \times f\left(t-t^{\prime}\right) d t^{\prime}
\end{aligned}
$$

where $F_{\text {area }}$ is the radiative forcing in the particular area (NHml is Northern Hemisphere mid-latitudes, SHext is Southern Hemisphere extratropics), and the $k_{\mathrm{x}, \mathrm{y}}$ 's are the response coefficients giving temperature response in the area $y$ to forcing in area $\mathrm{x}$ (Table 3). The first term in the integral represents the RF weighted by regional sensitivities while the second term, $f(t)$, describes the climate system's inertial response. The latter is defined as:

$$
f(t)=0.541 / 8.4 \exp (-t / 8.4)+0.368 / 409.5 \exp (-t / 409.5)
$$

where $t$ is the time in years and the two exponentials represent the relatively rapid response of the land and upper ocean and the slower response of the deep ocean as reported for simulations with the Hadley Centre climate model (Boucher et al., 2009), with absolute responses scaled by 0.857 to match the transient climate sensitivity of the GISS model for consistency with the other model results used here (and as the sensitivity in the simulations used to derive the responses was high even compared with standard Hadley Centre simulations). The sum of the first coefficients in each term, 0.541 and 0.369 , gives the approximate equilibrium climate sensitivity assumed here $\left(0.91 \mathrm{C}\right.$ per $\mathrm{W} / \mathrm{m}^{2}$; corresponding to $3.4 \mathrm{C}$ for a doubling of $\mathrm{CO}_{2}$ ). We do not account for any regional differences in response times, as over the decadal and longer timescales we are interested in we expect these to be of minor importance. Calculations were performed for each latitude band and for the global mean (the latter is, unsurprisingly, approximately equal to the area-weighted sum of the regional changes). In each case, our median estimate of aerosol direct + indirect forcing was included.

The resulting estimates of surface temperature change are meant to be illustrative, as the transient response may be different for forcing with alternate spatial and temporal behavior to the forcing used in the simulations from which we took the sensitivities. Ensemble simulations of a full climate model could examine the response in a more realistic manner, but are computationally expensive. These calculations, though simplified, are nonetheless useful in providing a qualitative picture of the historical and potential future impacts of coal-burning emissions on surface temperature. Note that in the HighG_earlyAQ case, for which forcing is from $\mathrm{CO}_{2}$ alone, our response is $\sim 2.1 \mathrm{C}$ per trillion tons of cumulative carbon released, near the upper edge of the range of
Table 3. Regional response coefficients ( $\mathrm{C}$ per W/m² local forcing).

\begin{tabular}{llllll}
\hline Forcing region & SHext & Tropics & NHml & Arctic & Global \\
\hline Response region & & & & & \\
SHext & 0.19 & 0.05 & 0.02 & 0.00 & 0.39 \\
Tropics & 0.09 & 0.24 & 0.10 & 0.02 & 0.47 \\
NHml & 0.07 & 0.17 & 0.24 & 0.06 & 0.53 \\
Arctic & 0.06 & 0.16 & 0.17 & 0.31 & 0.64 \\
\hline
\end{tabular}

Regional responses per unit forcing are the mean of responses to $\mathrm{CO}_{2}$ and sulfate taken from Fig. 1 of (Shindell and Faluvegi, 2009).

$\sim 0.9-2.2$ C per trillion tons carbon inferred from observations (Matthews et al., 2009).

The results show that the Northern Hemisphere midlatitude band responds more strongly to the projected RF changes than the global mean owing to its greater climate sensitivity (due to local cloud, water vapor and surface albedo feedbacks), while the Southern Hemisphere extratropics respond more slowly (Fig. 5). The timing of pollution controls has an enormous influence on the climate response during the first seven decades, but only a modest influence remains three decades after controls are imposed. Perhaps most significant is that the rates of warming are dramatically different in the cases with early or late pollution controls. The maximum decadal $\mathrm{NHml}$ warming in the early pollution controls case is $0.20 \mathrm{C} /$ decade, whereas it is $0.49 \mathrm{C} /$ decade in the late pollution controls case. The tropics also experiences considerably faster warming rates in the late pollution control scenario than with early pollution controls (tropical warming is very similar to the global mean values shown in Fig. 5). This may have profound effects on biological systems which face increasing difficulty in adapting to more rapid warming (Loarie et al., 2009). The Arctic response in the early pollution control scenario is qualitatively similar to other regions, but rises to more than $1.5 \mathrm{C}$ by 2100 . In the late pollution controls case, Arctic temperature changes are less than NHml or global mean changes during 2000 to 2050, as the mid-latitude negative forcing is partially offset by local positive forcing (Fig. 4), but warming again becomes greater in the Arctic than anywhere else past 2070.

A similar analysis can be done for the 20th century. We first consider the historical emissions patterns. Total sulfur emissions from coal burning increased markedly from the late 19th century until World War I, remained fairly level during the interwar years, and then again began a steady increase. These patterns largely followed usage, as there were only minimal pollution control efforts prior to the 1970s. Due to both pollution controls and a switch to low-sulfur coal, the rate of increase in sulfur emissions from coal burning began to slow during the 1970s, peaking around 1990 and then decreasing so that 2000 emissions are comparable to 1970 levels (Smith et al., 2004, 2001). Global sulfur 

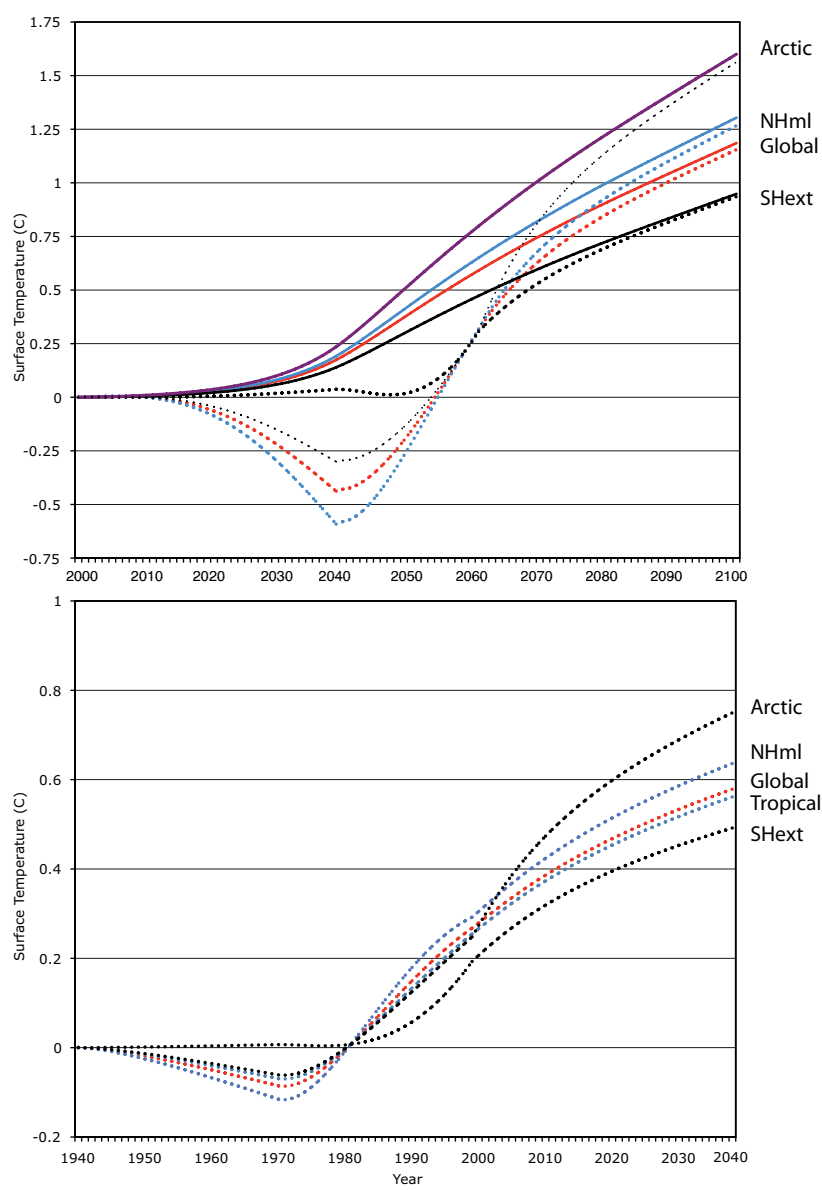

ing is also important. Total production of coal in the US followed a similar trend to global usage, increasing greatly from the late 19th century through about 1915 and then leveling off, but production increased sharply again from 1960 onwards (Lefohn et al., 1999). As early usage was greatest in the US and Europe (Smith et al., 2004; Lefohn et al., 1999), the period up to 1970 would have seen substantial negative NHml forcing, with positive forcing over most of the Southern Hemisphere and the tropics (similar to that shown in Fig. 4, but shifted slightly northward as in Shindell et al., 2008a). Since the 1970s, RF is likely to have increased more at Northern Hemisphere mid- to high-latitudes than at lower latitudes owing to reductions in air quality pollutant emissions in developed nations and increases in emissions in developing countries.

To illustrate this, we performed surface temperature response calculations analogous to those done for the future scenarios but using the spatial pattern of North American and European power sector emissions (Shindell et al., 2008a) and scaling the $\mathrm{CO}_{2}$ and sulfate forcings to the historical emissions given above for the period 1940-2000. We evaluate the response to these forcings to gauge the effect of the broad shift from pre-1970 coal-fired power plant emissions without pollution controls to post-1970 emissions with pollution controls. We find that this shift likely contributed to the accelerated global warming of recent decades relative to the mid-20th century, and to the initially slower but subsequently more rapid rise in $\mathrm{NHml}$ temperatures relative to the global mean or Southern Hemisphere extratropics (Fig. 5). Though our values are only rough estimates, we note that from 1970 to 2000 global mean temperatures increased by $\sim 0.4 \mathrm{C}$ (Hansen et al., 2001), while NHml temperatures rose about $0.8 \mathrm{C}$ and the Southern Hemisphere extratropics warmed $\sim 0.2 \mathrm{C}$ (Shindell and Faluvegi, 2009). Hence it seems plausible that emissions from coal burning power plants could account for a substantial portion of the post-1970 global and regional warming trends. An overall cooling influence of fossil fuel emissions on NHml during the mid-20th century was also seen in an earlier study (Hunter et al., 1993), though that did not isolate the effects of coal from other fuels and extended only through 1989. A definitive attribution of historical trends is difficult, however, owing to uncertainties in aerosol forcing, the influence of poorly-known emissions from other activities such as residential bio- or fossil-fuel burning, and the influence of internal variability. Note that again Arctic temperature responses would lie between the global and $\mathrm{NHml}$ temperatures.

Thus despite increases in coal usage from only a few $\mathrm{MtC}$ during the preindustrial to $\sim 1.3 \mathrm{GtC}$ by 1970 (roughly onethird of total global carbon emissions; Marland et al., 2008), the net impact of coal-burning emissions from power plants (the primary use of coal in the latter half of the 20th century) on surface temperature may have been weakly negative up to that time. The $\mathrm{CO}_{2}$ emissions from that time will continue to influence climate for centuries however, eventually leading 
to a substantial warming. This can be seen in the strong warming response during 2000 to 2040 that results from the combined effect of historical emissions of $\mathrm{CO}_{2}$ and constant year 2000 emissions (Fig. 5; lower panel). It's clear that this warming is driven by the response to pre-2000 emissions of $\mathrm{CO}_{2}$ since the forcing from constant current emissions alone is negative for the 2000-2020 period (Fig. 1).

The influence of coal-burning in the early 20th century is more difficult to assess. The rapid increase in US coal usage from $\sim 1900$, when it was $\sim 200 \mathrm{Mt}$, to 1915 , when it reached $\sim 550 \mathrm{Mt}$ (EIA, 2009), was accompanied by concomitant increases in sulfur emissions which likely masked much of the warming from $\mathrm{CO}_{2}$. However, coal usage at that time primarily consisted of residential and industrial uses, not electricity generation. These types of combustion are typically much less complete, and hence emit large quantities of black carbon, a powerful positive short-lived radiative forcing agent. Consistent with this, the abundance of black carbon in ice cores from Greenland, downwind of the US, peaks in the early 20th century (McConnell et al., 2007). Hence even if the warming effect of $\mathrm{CO}_{2}$ was largely offset by increased sulfur emissions, the net effect of emissions from the rapid increase in early 20th century coal burning would likely have been a positive RF. This may have contributed to the observed global and regional warming during roughly 1915-1930 (assuming a 1-2 decade lag in climate response to forcing). From $\sim 1950$ to 2000 , usage of coal to generate electricity increased from $\sim 20 \%$ of the total US usage to $\sim 90 \%$ (it was $\sim 54 \%$ in China in 2000 , and $\sim 70 \%$ in India). Hence current emissions from coal burning without pollution controls are much more likely to have near-zero net short-term forcing than those of the early 20th century.

\section{Uncertainties and limitations}

There are many sources of uncertainty in estimating the climate impact of future emissions, including the emission scenarios, the emissions themselves, the chemistry model and the climate response calculations. Beginning with the scenarios, the socio-economic factors that govern future growth rates cannot be reliably predicted and emissions projections are based on many assumptions. While we investigated two possible growth rates to explore sensitivity, actual trends will vary from either of those idealized projections. Under the high growth scenario, coal usage is $9.6 \mathrm{Gt}$ coal in China and India for power generation at 2030, while under the moderate growth scenario it is $2.3 \mathrm{Gt}$ coal. EIA projections have $3.8 \mathrm{Gt}$ coal usage by China at 2030 and $0.6 \mathrm{Gt}$ coal by India for all purposes ( $\sim 60-70 \%$ of current coal usage in China and India is for power (Streets et al., 2003), so $\sim 2.6-3.1$ Gt of the total), so our scenarios bracket those projections although our moderate scenario is much closer. The EIA projected growth rate for China decreases from 6\% during 2005-2010 to less than $3 \%$ after 2015, however. As noted previously, histori- cal growth rates have been substantially greater, so it is not obvious which path will be closer to actual future emissions.

Our scenarios also assume that when air quality pollutant controls are introduced, they are $100 \%$ effective. Though this is clearly unrealistic, the impact of residual emissions when controls are in place is likely to be quite small based on current US emissions and trends. Current air quality pollutant emissions from US coal-fired power plants create an annual average RF of less than $0.1 \mathrm{~W} / \mathrm{m}^{2}$ despite $\mathrm{CO}_{2}$ emissions more than double those of China and India (Table 2). More importantly, from 1998 to 2007, US emissions of $\mathrm{SO}_{2}$ and $\mathrm{NO}_{\mathrm{x}}$ decreased by $\sim 30 \%$ and $40 \%$, respectively. This occurred despite an overall growth in coal usage (resulting in $\mathrm{CO}_{2}$ emissions increasing by $\sim 7 \%$ ) and air quality pollutant emissions in 1998 that were already quite reduced compared with 1970s levels. Further decreases are expected, demonstrating that technology exists to remove the vast majority of $\mathrm{SO}_{2}$ and $\mathrm{NO}_{\mathrm{x}}$ emissions, so that the $\mathrm{RF}$ from residual air quality pollutant emissions if strict controls were put in place would be very small.

Our scenarios were also limited in that they explored only the impact of hypothetical additional emissions from China and India. EIA projections of total coal usage for 2005 to 2030 show $80 \%$ of total growth in these two countries, with the remainder divided nearly equally between the US and the developing world (the latter mostly in other Asian countries). It is not completely clear how much of this growth is due to usage in power plants, however, and residential and industrial use of coal may have rather different effects as it also leads to substantial emissions of carbon monoxide, black and organic carbon. Nonetheless, we can roughly estimate the contributions from other regions. The contribution of additional coal burning plants in Asia would add $\sim 10-15 \%$ to the estimated contribution from China and India using the EIA growth rates. The contribution of added US power plants, which are projected to grow at $1.1 \% / \mathrm{yr}$ (EIA, 2009) and we assume generate exclusively $\mathrm{CO}_{2}$ emissions, would be an additional $\mathrm{RF}$ of $0.08 \mathrm{~W} / \mathrm{m}^{2}$ at 2030 and $0.19 \mathrm{~W} / \mathrm{m}^{2}$ at 2080 from plants added between 2005 and 2030. Hence to get an estimate of the global forcing from worldwide addition of coal-fired power plants, $\sim 20-40 \%$ would be added to the total 2080 forcing from power plants in China and India, depending upon the scenario assumed for those countries (Fig. 2). An estimate of the total forcing from coalfired power plants should also include the forcing from existing power plants worldwide. This adds roughly another $0.4 \mathrm{~W} / \mathrm{m}^{2}$ at 2080 , though the value would be higher if pollution controls were improved on existing plants; with a maximum addition of $\sim 0.25 \mathrm{~W} / \mathrm{m}^{2}$ if all current air quality pollutant emissions were eliminated (Fig. 1). However, the value could also be lower if plants are taken out of commission, but again, neither future application of pollutant controls nor plant lifetimes cannot be reliably projected.

Another large source of uncertainty is our incomplete knowledge of the emission factors for coal combustion and 
from the substantial variation from location to location that results from differences in coal burning techniques and in the composition of the source coal, especially its sulfur content. The leads to a very large range in emission factors for $\mathrm{SO}_{2}$, which spans $4-113 \mathrm{~g} \mathrm{SO}_{2} / \mathrm{kg}$ coal for China and $8-16 \mathrm{~g} / \mathrm{kg}$ for India (Streets et al., 2003). Values for $\mathrm{NO}_{\mathrm{x}}$ are more consistent, with a range of $5-12 \mathrm{~g} \mathrm{NO}_{2} / \mathrm{kg}$ coal for both countries, while the emission factors for $\mathrm{CO}_{2}$ are quite well known, with a range of only $2243-2313 \mathrm{~g} / \mathrm{kg}$. We used emission factors of $16 \mathrm{~g} / \mathrm{kg}$ for China and $12 \mathrm{~g} / \mathrm{kg}$ for India for $\mathrm{SO}_{2}$, and $8 \mathrm{~g} / \mathrm{kg} \mathrm{NO}_{\mathrm{x}}$ and $2278 \mathrm{~g} / \mathrm{kg} \mathrm{CO}_{2}$ for both countries, leading to the current emissions given in Table 2. For comparison, another estimate gives $8.9 \mathrm{Mt}$ for Chinese $\mathrm{SO}_{2}$ emissions from coal-burning power plants in 2000 (Yang and Schreifels, 2003), and hence is somewhat larger than the 5.4 Mt value we used, highlighting the uncertainty in current sulfur emissions. Future emission factors could be substantially different, depending, for example, on the availability of low-sulfur coal as demand increases. This would clearly affect the magnitude of air quality pollutant RF during the period prior to full pollution controls taking effect.

Future technology may also be developed to limit carbon dioxide emissions. Were carbon capture and sequestration (CCS) technology to be eventually commercialized and deployed, additional $\mathrm{CO}_{2}$ emissions after CCS was installed might be dramatically lower. However, emissions up through the time of CCS installation would continue to drive a slow increase in atmospheric $\mathrm{CO}_{2}$, leading to a continued increase in RF (albeit a much slower one than in our scenarios). Given the time required to perfect and expand the technology, as well as to deploy an enormous network of $\mathrm{CO}_{2}$ pipelines, it seems extremely unlikely that CCS will be operating on a majority of power plants during the next several decades. We note also that even with CCS, emissions of $\mathrm{CO}_{2}$ are still estimated at 255-442 $\mathrm{g} / \mathrm{kWh}$ from extraction and transportation of coal and residual emissions versus $790-1020 \mathrm{~g} / \mathrm{kWh}$ without CCS (Jacobson, 2009). This highlights how consideration of the full life-cycle of coal use would become increasingly important as pollution controls at the power plants themselves become more effective.

The models used in this study also have their limitations and uncertainties. The atmospheric composition model was run at $4 \times 5$ degree horizontal resolution, which may limit its ability to accurately represent some aspects of atmospheric chemistry and of the interaction between small-scale cloud processes and gases or aerosols. Comparison of multiple models provides an idea of the uncertainty associated with differing physical representations of chemistry and coupling to the hydrologic cycle. For example, both the sulfate burden per unit $\mathrm{SO}_{2}$ emission and the RF per Tg sulfate burden were $\sim 40-45 \%$ greater in the GFDL model than in the GISS model in a recent study (Shindell et al., 2008b). Across a wide range of models, the standard deviation of sulfate aerosol RF per unit load was found to be $24 \%$ (Schulz et al., 2006). These uncertainties are consistent with the large possible range for estimates of aerosol effects used here, as discussed previously. Additionally, the model used here did not include mixing of different aerosol types (so-called "internal" mixing). This can influence the optical properties of sulfate in the presence of other types of particulate such as black carbon.

Finally, the climate response calculation used here was of course a highly simplified representation of the climate system. Future work using improved modeling tools would help determine the importance of these various factors, though we do not expect them to change the overall qualitative picture presented here (given the large uncertain in aerosol forcing included already). Future work could also explore aspects of the climate response to emissions other than surface temperature, such as circulation or precipitation (e.g. Ming and Ramaswamy, 2009; Wang et al., 2009).

\section{Impacts and conclusions}

Aside from their impact on climate and air pollution, coal plants are the largest anthropogenic source of mercury emissions, with emissions from Chinese coal burning alone accounting for $\sim 5 \%$ of global discharge in 1995 (Zhang et al., 2002). With usage of coal in China having increased by $\sim 75 \%$ between 1995 and 2006 (EIA, 2009), China's mercury emissions from coal burning may already be nearly $10 \%$ of global emissions. In addition, coal burning generates more than 125 million tons of waste (ash, sludge and slag) each year in the US annually (Environmental Protection Agency, 1999; The New York Times, 2009), roughly the same amount of waste as the municipal solid waste sent to landfills from every city in the country. This coal combustion waste contains lead, mercury, and arsenic, and the EPA has identified 63 sites where heavy metals from coal waste ponds have contaminated ground water in the US (The New York Times, 2009). Coal mining itself generates additional emissions, including methane vented from mines and emissions from mechanical extraction and transportation of coal, and can lead to environmental damage such as filling in streams with earth from mountaintop removal. As discussed previously, there are substantial adverse impacts on human health from the fine particulate formed from coal burning emissions, with estimated impact on more than 20000 US lives each year and substantially larger numbers in Asia where hazardous trace elements such as arsenic or fluorine are emitted during residential coal burning (Finkelman et al., 1999). Ideally, assessment of the environmental effects of coal-fired power plants should include all these effects, especially when the cost of electricity from these plants is compared with alternative sources of electricity generation.

We find that while the near-term effect of air quality pollutants is to mask warming by $\mathrm{CO}_{2}$, leading to a net overall near-term cooling effect, this does not imply that warming will not eventually take place. Worldwide application 
of pollution control technology in use in Western developed countries and Japan along with continued $\mathrm{CO}_{2}$ emissions would lead to strong positive forcing in the long term irrespective of whether the pollution controls are applied immediately or several decades from now. Continued emissions at current (year 2000) pollutant and $\mathrm{CO}_{2}$ levels may have little near-term effect on climate, but the climate 'debt' from $\mathrm{CO}_{2}$ forcing will continue to mount. Once pollution controls are put into place as society demands cleaner air it will rapidly come due, leading to a "double warming" effect (Fuglestvedt et al., 2009) as simultaneous reductions in sulfate and increases in $\mathrm{CO}_{2}$ combine to accelerate global warming. The only way to avoid this would be not to impose pollution controls and to perpetually increase sulfur-dioxide emissions, which would lead to a staggering cost in human health and is clearly unsustainable.

Our results also demonstrate that regional forcing and resulting regional climate change may substantially depart from the global mean when emissions include both shortand long-lived pollutants (as in other sectoral studies such as Shindell et al., 2008a; Aunan et al., 2009). This reinforces the fact that metrics which may be useful at the global scale, such as global mean RF or global warming potential (GWP) summed over the various emitted species, are inadequate to describe regional changes. The case of zero net global mean forcing at 2046 (Fig. 3) exemplifies this limitation as regional responses are certainly non-zero (Fig. 5). Our results demonstrate that owing to the different lifetimes of climate forcing agents, emissions from a particular activity can have greatly differing impacts on areas near to and far from the emission sources. As surface temperature responses are related to forcing location (Shindell and Faluvegi, 2009), this suggests that regional forcing may be a more useful indicator of regional climate response than global forcing in cases with substantial forcing from air quality pollutants. The regional temperature response calculations we introduce here (Sect. 5) could be computed for a variety of emission scenarios were regional forcings known, and would also allow computation of regional temperature potentials as metrics. These may provide useful insight into regional impacts.

Design of metrics that capture rates of climate change poses further challenges. We showed that the timing of pollution controls greatly influenced the maximum rate of warming that takes place. A standard metric such as GWP integrates RF from an emissions pulse over time, so if GWPs from time-varying emissions were summed at a particular point in time (e.g. 100-years in the future), they would show an effect were air quality pollutants included in addition to $\mathrm{CO}_{2}$, but they would not clearly reveal the maximum warming rate during that time. A metric such as global temperature potential (GTP) (Shine et al., 2005) could also be used to assess the impact of time-varying emissions by summing their GTPs. For the latter part of our simulations, it would show little difference between the early and late pollution control scenarios as the 2080-2100 temperature changes are quite similar (Fig. 5), and thus would also not reveal the stark regional and temporal differences between the scenarios. Global metrics can be quite useful for estimating certain quantities at specific times, and they would likely characterize the response to $\mathrm{CO}_{2}$ emissions quite well as this response is much more spatially and temporally smooth (e.g. Figs. 4 and 5). However, the results presented here highlight how a global metric used at a particular time horizon provides only a rather limited view of some of the most important impacts when multiple-pollutant emission scenarios are considered. Hence policy decisions should ideally consider timedependent regional responses, though these are clearly much more complex than using a global metric evaluated at a single point in time.

The results demonstrate that decisions made for the sake of air quality policy will have an enormous impact on climate forcing from coal-fired power plants over the next several decades (consistent with implications of other studies, e.g. Dufresne et al., 2005; Shindell et al., 2008b; Hayhoe et al., 2002; Levy et al., 2008; Kloster et al., 2008, 2009). For comparison, the total forcing from all activities and emissions was estimated to range from 2.8 to $6.6 \mathrm{~W} / \mathrm{m}^{2}$ at 2080 under the scenarios used in recent IPCC assessments (Intergovernmental Panel on Climate Change, 2001). Hence the $\sim 1.5-2 \mathrm{~W} / \mathrm{m}^{2}$ forcing under the high growth scenarios (Fig. 2 for Asia plus the US contribution discussed in the text) indicates the potential of continued addition of coalburning power plants in China, India and the US to contribute a substantial fraction of the total projected climate forcing. A relatively steady warming would result from the gradual rise in RF under the early pollution control scenarios. In contrast, late application of pollution controls would lead to coal-burning emissions from power plants contributing a moderate cooling globally and at Northern Hemisphere mid-latitudes during the first half of the century in the various scenarios. Such an effect could in fact already be contributing to the slower rates of warming during the 21 st century relative to the latter decades of the 20th, though this might also result from internal variability (Easterling and Wehner, 2009). However, emissions under the late pollution controls case would exert a strong warming influence in the latter part of the century as the aerosol masking of $\mathrm{CO}_{2} \mathrm{RF}$ is removed, leading to extremely rapid warming rates, especially at Northern Hemisphere mid-latitudes. While the relatively high growth rates assumed here may provide an upper estimate of the total magnitude of climate forcing, in January 2009 the Chinese government announced plans to increase coal production $30 \%$ by 2015 to meet its energy needs (The China Post, 2009), so substantial growth does seem likely.

Acknowledgements. We thank G. A. Schmidt and two anonymous reviewers for helpful comments and NASA for supporting this work.

Edited by: J. Quaas 


\section{References}

Andreae, M. O., Jones, C. D., and Cox, P. M.: Strong present-day aerosol cooling implies a hot future, Nature, 435, 1187-1190, 2005.

Aunan, K., Berntsen, T. K., Myhre, G., Rypdal, K., Streets, D. G., Woo, J., and Smith, K. R.: Radiative forcing from household fuel burning in Asia, Atmos. Env., 43, 5674-5681, 2009.

Bauer, S. E., Koch, D., Unger, N., Metzger, S. M., Shindell, D. T., and Streets, D. G.: Nitrate aerosols today and in 2030: a global simulation including aerosols and tropospheric ozone, Atmos. Chem. Phys., 7, 5043-5059, 2007, http://www.atmos-chem-phys.net/7/5043/2007/.

Berntsen, T. K., Fuglestvedt, J. S., Myhre, G., Stordal, F., and Berglen, T.: Abatement of greenhouse gases: Does location matter?, Clim. Change, 74, 377-411, 2006.

Boer, G. and Yu, B.: Climate sensitivity and response, Clim. Dyn., 20, 415-429, 2003.

Charlson, R. J., Schwartz, S. E., Hales, J. M., Cess, R. D., Coakley, J. A. J., Hansen, J. E., and Hofmann, D. J.: Climate forcing by anthropogenic aerosols, Science, 255, 423-430, 1992.

Dentener, F., Stevenson, D., Cofala, J., Mechler, R., Amann, M., Bergamaschi, P., Raes, F., and Derwent, R.: The impact of air pollutant and methane emission controls on tropospheric ozone and radiative forcing: CTM calculations for the period 19902030, Atmos. Chem. Phys., 5, 1731-1755, 2005, http://www.atmos-chem-phys.net/5/1731/2005/.

Dufresne, J.-L., Quaas, J., Boucher, O., Denvil, S., and Fairhead, L.: Contrasts in the effects on climate of anthropogenic sulfate aerosols between the 20th and the 21st century, Geophys. Res. Lett., 32, L21703, doi:10.1029/2005GL023619, 2005.

Easterling, D. R. and Wehner, M. F.: Is the climate warming or cooling?, Geophys. Res. Lett., 36, L08706, doi:10.1029/2009GL037810, 2009.

Environmental Protection Agency: Technical background document for the supplemental report to congress on remaining fossil fuel combustion wastes: Industry statistics and waste management practices, US EPA, 61, 1999.

Finkelman, R. B., Belkin, H. E., and Zheng, B.: Health impacts of domestic coal use in China, Proc. Natl. Acad. Sci., 96, 34273431, 1999.

Forster, P., Ramaswamy, V., Artaxo, P., Berntsen, T., Betts, R., Fahey, D. W., Haywood, J. L., J., Lowe, D. C., Myhre, G., Nganga, J., Prinn, R., Raga, G., Schulz, M., and Van Dorland, $\mathrm{R}$.: Changes in atmospheric constituents and in radiative forcing, in: Climate change 2007: The physical science basis, edited by: Solomon, S., Cambridge University Press, New York, 2007.

Fuglestvedt, J., Berntsen, T., Myhre, G., Rypdal, K., and Skeie, R. B.: Climate forcing from the transport sectors, Proc. Natl. Acad. Sci., 105, 454-458, 2008.

Fuglestvedt, J. S., Berntsen, T. K., Eyring, V., Isaksen, I. S., Lee, D., and Sausen, R.: Shipping emissions: From cooling to warming of climate - and reducing impacts on health, Environ. Sci. Technol., 43, 9057-9062, 2009.

Hansen, J., Ruedy, R., Sato, M., Imhoff, M., Lawrence, W., Easterling, D., Peterson, T., and Karl, T.: A closer look at United States and global surface temperature change, J. Geophys. Res., 106, 23947-23963, 2001.

Hansen, J., Sato, M., Ruedy, R., Kharecha, P., Lacis, A., Miller, R. L., Nazarenko, L., Lo, K., Schmidt, G. A., Russell, G., Aleinov,
I., Bauer, S., Baum, E., Cairns, B., Canuto, V., Chandler, M., Cheng, Y., Cohen, A., Genio, A. D., Faluvegi, G., Fleming, E., Friend, A., Hall, T., Jackman, C., Jonas, J., Kelley, M., Kiang, N. Y., Koch, D., Labow, G., Lerner, J., Menon, S., Novakov, T., Oinas, V., Perlwitz, J., Perlwitz, J., Rind, D., Romanou, A., Schmunk, R., Shindell, D., Stone, P., Sun, S., Streets, D., Tausnev, N., Thresher, D., Unger, N., Yao, M., and Zhang, S.: Climate simulations for 1880-2003 with GISS modelE, Clim. Dyn., 29, 661-696, 2007.

Hayhoe, K., Kheshgi, H. S., Jain, A. K., and Wuebbles, D. J.: Substitution of natural gas for coal: Climatic effects of utility sector emissions, Clim. Change, 54, 107-139, 2002.

Hunter, D. E., Schwartz, S. E., Wagener, R., and Benkovitz, C. M.: Seasonal, latitudinal, and secular variations in temperature trends: Evidence for influence of anthropogenic sulfate, Geophys. Res. Lett., 20, 2455-2458, 1993.

Intergovernmental Panel on Climate Change: Climate change 2001, edited by: Houghton, J. T., Ding, Y., Griggs, D. J., et al., Cambridge University Press, Cambridge, 881 pp., 2001.

Jacobson, M. Z.: Review of solutions to global warming, air pollution, and energy security, Energy Environ. Sci., 2, 148-173, 2009.

Jones, A., Haywood, J. M., and Boucher, O.: Aerosol forcing, climate response and climate sensitivity in the Hadley Centre climate model, J. Geophys. Res., 112, D20211, doi:10.1029/2007JD008688, 2007.

Kinne, S., Schulz, M., Textor, C., Guibert, S., Balkanski, Y., Bauer, S. E., Berntsen, T., Berglen, T. F., Boucher, O., Chin, M., Collins, W., Dentener, F., Diehl, T., Easter, R., Feichter, J., Fillmore, D., Ghan, S., Ginoux, P., Gong, S., Grini, A., Hendricks, J., Herzog, M., Horowitz, L., Isaksen, I., Iversen, T., Kirkevåg, A., Kloster, S., Koch, D., Kristjansson, J. E., Krol, M., Lauer, A., Lamarque, J. F., Lesins, G., Liu, X., Lohmann, U., Montanaro, V., Myhre, G., Penner, J., Pitari, G., Reddy, S., Seland, O., Stier, P., Takemura, T., and Tie, X.: An AeroCom initial assessment - optical properties in aerosol component modules of global models, Atmos. Chem. Phys., 6, 1815-1834, 2006,

http://www.atmos-chem-phys.net/6/1815/2006/.

Kloster, S., Dentener, F., Feichter, J., Raes, F., van Aardenne, J., Roeckner, E., Lohmann, U., Stier, P., and Swart, R.: Influence of future air pollution mitigation strategies on total aerosol radiative forcing, Atmos. Chem. Phys., 8, 6405-6437, 2008, http://www.atmos-chem-phys.net/8/6405/2008/.

Kloster, S., Dentener, F., Feichter, J., Raes, F., Lohmann, U., Roeckner, E., and Fischer-Bruns, I.: A GCM study of future climate response to aerosol pollution reductions, Clim. Dynam., doi:10.1007/s00382-009-0573-0, in press, 2009.

Koch, D., Schmidt, G., and Field, C.: Sulfur, sea salt and radionuclide aerosols in giss modele, J. Geophys. Res., 111, D06206, doi:10.1029/2004JD005550, 2006.

Koch, D., Bond, T., Streets, D., and Unger, N.: Linking future aerosol radiative forcing to shifts in source activities, Geophys. Res. Lett., 34, L05821, doi:10.1029/2006GL028360, 2007.

Kvalevåg, M. M. and Myhre, G.: Human impact on direct and diffuse solar radiation during the industrial era, J. Clim., 20, 48744883, 2007.

Lefohn, A. S., Husar, J. D., and Husar, R. B.: Estimating historical anthropogenic global sulfur emission patterns for the period 1850-1990, Atmos. Env., 33, 3435-3444, 1999. 
Levy, H., Schwarzkopf, M. D., Horowitz, L., Ramaswamy, V., and Findell, K. L.: Strong sensitivity of late 21 st century climate to projected changes in short-lived air pollutants, J. Geophys. Res., 113, D06102, doi:10.1029/2007JD009176, 2008.

Loarie, S. R., Duffy, P. B., Hamilton, H., Asner, G. P., Field, C. B., and Ackerly, D. D.: The velocity of climate change, Nature, 462, 1052-1055, 2009.

Marland, G., Boden, T. A., and Andres, R. J.: Global, regional, and national fossil fuel $\mathrm{CO}_{2}$ emissions, in trends: A compendium of data on global change, Carbon Dioxide Information Analysis Center, Oak Ridge National Laboratory, US Department of Energy, Oak Ridge, 2008.

Matthews, H. D., Gillett, N. P., Stott, P. A., and Zickfeld, K.: The proportionality of global warming to cumulative carbon emissions, Nature, 459, 829-832, 2009.

McConnell, J., Edwards, R., Kok, G., Flanner, M., Zender, C., Saltzman, E., Banta, J., Pasteris, D., Carter, M., and Kahl, J.: 20th-century industrial black carbon emissions altered Arctic climate forcing, Science, 317, 1381-1384, 2007.

Ming, Y. and Ramaswamy, V.: Nonlinear climate and hydrological responses to aerosol effects, J. Climate, 22, 1329-1339, 2009.

Mitchell, J. F. B., Davis, R. A., Ingram, W. J., and Senior, C. A.: On surface temperature, greenhouse gases, and aerosols: Models and observations, J. Clim., 8, 2364-2386, 1995.

Nakicenovic, N., Alcamo, J., Davis, G., et al.: IPCC special report on emissions scenarios, Cambridge University Press, Cambridge, UK, 570 pp., 2000.

Penner, J. E., Quaas, J., Storelvmo, T., Takemura, T., Boucher, O., Guo, H., Kirkevåg, A., Kristjánsson, J. E., and Seland, Ø.: Model intercomparison of indirect aerosol effects, Atmos. Chem. Phys., 6, 3391-3405, 2006, http://www.atmos-chem-phys.net/6/3391/2006/.

Prather, M. J., Ehhalt, D., Dentener, F., Derwent, R. G., Dlugokencky, E. J., Holland, E. A., Isaksen, I. S., Katima, J., Kirchhoff, V., Matson, P., Midgley, P., and Wang, M.: Atmospheric chemistry and greenhouse gases, in: Climate change 2001, edited by: Houghton, J. T., Cambridge Univ. Press, Cambridge, 239-287, 2001.

Quaas, J., Boucher, O., Bellouin, N., and Kinne, S.: Satellite-based estimate of the direct and indirect aerosol climate forcing, J. Geophys. Res., 113, D05204, doi:10.1029/2007JD008962, 2008.

Ramanathan, V. and Feng, Y.: On avoiding dangerous anthropogenic interference with the climate system: Formidable challenges ahead, Proc. Natl. Acad. Sci., 105, 14245-14250, 2008.

Ramaswamy, V., Boucher, O., Haigh, J. D., Hauglustaine, D. A., Haywood, J., Myhre, G., Nakajima, T., Shi, G. Y., and Solomon, S.: Radiative forcing of climate change, in: Climate change 2001, edited by: Houghton, J. T., Cambridge Univ. Press, Cambridge, 349-416, 2001.

Schmidt, G. A., Ruedy, R., Hansen, J. E., Aleinov, I., Bell, N., Bauer, M., Bauer, S., Cairns, B., Canuto, V., Cheng, Y., Del Genio, A., Faluvegi, G., Friend, A. D., Hall, T. M., Hu, Y., Kelley, M., Kiang, N. Y., Koch, D., Lacis, A. A., Lerner, J., Lo, K. K., Miller, R. L., Nazarenko, L., Oinas, V., Perlwitz, J., Perlwitz, J., Rind, D., Romanou, A., Russell, G. L., Sato, M., Shindell, D. T., Stone, P. H., Sun, S., Tausnev, N., Thresher, D., and Yao, M.-S.: Present day atmospheric simulations using GISS modelE: Comparison to in-situ, satellite and reanalysis data, J. Clim., 19, 153-192, 2006.
Schulz, M., Textor, C., Kinne, S., Balkanski, Y., Bauer, S., Berntsen, T., Berglen, T., Boucher, O., Dentener, F., Guibert, S., Isaksen, I. S. A., Iversen, T., Koch, D., Kirkevåg, A., Liu, X., Montanaro, V., Myhre, G., Penner, J. E., Pitari, G., Reddy, S., Seland, Ø., Stier, P., and Takemura, T.: Radiative forcing by aerosols as derived from the AeroCom present-day and pre-industrial simulations, Atmos. Chem. Phys., 6, 5225-5246, 2006 ,

http://www.atmos-chem-phys.net/6/5225/2006/.

Shindell, D.: Local and remote contributions to Arctic warming, Geophys. Res. Lett., 34, L14704, doi:10.1029/2007GL030221, 2007.

Shindell, D., Lamarque, J.-F., Unger, N., Koch, D., Faluvegi, G., Bauer, S., Ammann, M., Cofala, J., and Teich, H.: Climate forcing and air quality change due to regional emissions reductions by economic sector, Atmos. Chem. Phys., 8, 7101-7113, 2008, http://www.atmos-chem-phys.net/8/7101/2008/.

Shindell, D. and Faluvegi, G.: Climate response to regional radiative forcing during the 20th century, Nature Geosci., 2, 294-300, 2009.

Shindell, D. T., Faluvegi, G., Bell, N., and Schmidt, G. A.: An emissions-based view of climate forcing by methane and tropospheric ozone, Geophys. Res. Lett., 32, L04803, doi:10.1029/2004GL021900, 2005.

Shindell, D. T., Faluvegi, G., Unger, N., Aguilar, E., Schmidt, G. A., Koch, D. M., Bauer, S. E., and Miller, R. L.: Simulations of preindustrial, present-day, and 2100 conditions in the NASA GISS composition and climate model G-PUCCINI, Atmos. Chem. Phys., 6, 4427-4459, 2006, http://www.atmos-chem-phys.net/6/4427/2006/.

Shindell, D. T., Faluvegi, G., Bauer, S. E., Koch, D. M., Unger, N., Menon, S., A., Miller, R. L., Schmidt, G. A., and Streets, D. G.: Climate response to projected changes in short-lived species under an A1B scenario from 2000-2050 in the GISS climate model, J. Geophys. Res., 112, D20103, doi:10.1029/2007JD008753, 2007.

Shindell, D. T., Levy II, H., Schwarzkopf, M. D., Horowitz, L. W., Lamarque, J.-F., and Faluvegi, G.: Multi-model projections of climate change from short-lived emissions due to human activities, J. Geophys. Res., 113, D11109, doi:10.1029/2007JD009152, 2008b.

Shindell, D. T., Faluvegi, G., Koch, D. M., Schmidt, G. A., Unger, N., and Bauer, S. E.: Improved attribution of climate forcing to emissions, Science, 326, 716-718, 2009.

Shine, K. P., Fuglestvedt, J. S., Hailemariam, K., and Stuber, N.: Alternatives to the global warming potential for comparing climate impacts of emissions of greenhouse gases, Clim. Change, 68, 281-302, 2005.

Siegenthaler, U. and Joos, F.: Use of a simple model for studying oceanic tracer distributions and the global carbon cycle, Tellus, 44, 186-207, 1992.

Smith, S. J., Pitcher, H., and Wigley, T. M. L.: Global and regional anthropogenic sulfur dioxide emissions, Global and Planetary Change, 29, 99-119, 2001.

Smith, S. J., Andres, R., Conception, E., and Lurz, J.: Sulfur dioxide emissions: 1850-2000, JGCRI Report, PNNL-14537, 2004.

Streets, D. G., Bond, T. C., Carmichael, G. R., Fernandes, S. D., Fu, Q., He, D., Klimont, Z., Nelson, S. M., Tsai, N. Y., Wang, M. Q., Woo, J.-H., and Yarber, K. F.: An inventory of gaseous and 
primary aerosol emissions in Asia in the year 2000, J. Geophys. Res., 108, 8809, doi:10.1029/2002JD003093, 2003.

Taylor, K. E. and Penner, J. E.: Response of the climate system to atmospheric aerosols and greenhouse gases, Nature, 369, 734737, 1994.

Unger, N., Shindell, D. T., Koch, D. M., and Streets, D. G.: Air pollution radiative forcing from specific emissions sectors at 2030, J. Geophys. Res., 113, D02306, doi:10.1029/2007JD008683, 2008.

Unger, N., Shindell, D. T., and Wang, J. S.: Climate forcing by the on-road transportation and power generation sectors, Atmos. Env., 43, 3077-3085, 2009.

Wang, C., Kim, D., Ekman, A. M. L., Barth, M. C., and Rasch, P. J.: Impact of anthropogenic aerosols on indian summer monsoon, Geophys. Res. Lett., 36, L21704, doi:10.1029/2009GL040114, 2009.
Wigley, T. M. L.: Could reducing fossil-fuel emissions cause global warming?, Nature, 349, 503-506, 1991.

Wild, O., Prather, M., and Akimoto, H.: Indirect long-term global radiative cooling from $\mathrm{NO}_{\mathrm{x}}$ emissions, Geophys. Res. Lett., 28, 1719-1722, 2001.

Yang, J. and Schreifels, J.: Implementing SO2 emissions in China OECD Global Forum on Sustainable Development: Emissions Trading, Paris, 2003,

Zhang, M. Q., Zhu, Y. C., and Deng, R. W.: Evaluation of mercury emissions to the atmosphere from coal combustion, China, Ambio, 31, 482-484, 2002. 